\title{
Effect of Histidine on Sensetivity of Some Pathogenic Bacteria
}

\author{
Fatima A. Abd Al-Jabar and Ali S. Ahmed \\ Department of Biotechnology, College of Science, University of Al-Nahrian, Baghdad-Iraq.
}

\begin{abstract}
The purpose of this study was to determine the antibacterial effect of the amino acid histidine against two pathogenic bacteria Escherichia coli and Staphylococcus aureus. No antibacterial activity was observed for histidine at all tested concentrations. The sensitivity test for E.coli and $S$. aureus was performed against ten types of antibiotics. The antibiotics used for E.coli were Levofloxacin(Lev), Streptomycin(S), Rifampicin(Rp), Metronidazole(Mz), Cloxacillin(Cx), Ciprofloxacin(Cip), Tetracycline(T), Nalidixic acid(Na), Penicillin(P) and Vancomycine(Va) and the results of inhibition zones were $44,14,8,0,0,35,24,28,16$ and $14 \mathrm{~mm}$ respectively. When the Histidine added at concentration $10 \mathrm{mg} / \mathrm{ml}$ to Mueller hintone agar, the inhibition zones became 24, $12,18,0,0,24,32,25,13$ and $14 \mathrm{~mm}$ for each antibiotic respectively. The antibiotics used forStaph. aureus areLevofloxacin (Lev), Gentamicin(Gm), Rifampicin(Rp), Metronidazole(Mz), Cloxacillin(Cx), Ciprofloxacin(Cip), Tetracycline(T), Clarithromycin(Cla), Vancomycine (Va) and Chloramphenicol (C). Result of inhibition zones were 40, 30, 0, 0, 0, 22, 10, 0, 10 and $22 \mathrm{~mm}$ when the Histidine added at concentration $10 \mathrm{mg} / \mathrm{ml}$ to the mueller hinton agar, the inhibition zones became 30, 20, 16, 0, 0, 26, 15, 0, 10 and $22 \mathrm{~mm}$. Applicable experiment of the histidine effect was conducted on resistant and sensitive isolates against Histidine of Mycobacterium tuberculosis (TB) in Pulmonary Institute in Baghdad. It was found that mixing of Histidine with Rifampicin changed the response of resistant isolate against Rifampicin and turned into sensitive. This results may encourage mixing antibiotics and Histidine instead of using the more effective and harmful antibiotics against the resistant isolates.
\end{abstract}

Keywords: Histidin, Pathogenic bacteria, Susceptibility test, Rifampicin.

\section{Introduction}

Histidine, an essential amino acid, has a side chain of positively charged imidazole functional group. The imidazole group makes it a common participant in enzyme catalyzed reactions. Unprotonated imidazole is nucleophile and can serve as a general base, while the protonated form can serve as general acid. The residue can also serve a role in stabilizing the folded structures of proteins [1]. The amino acid L-histidine (His) was discovered independently by Kossel and Hedin in 1896 [2]. The histidine has antibacterial activity[3]. Rifampicin inhibits bacterial DNAdependent RNA synthesis by inhibiting bacterial DNA-dependent RNA polymerase [4]. Rifampicin binds to RNA polymerase at a site adjacent to the RNA polymerase active center and blocks RNA synthesis by physically blocking the formation of the phosphodiester bond in the RNA backbone, preventing extension of RNA products beyond a length of 2-3 nucleotides ("steric-occlusion" mechanism) $[5,6]$.
Tuberculosis treatment refers to the medical treatment of the infectious disease tuberculosis (TB). The Rifampicin use in the first line of treatment of tuberculosis. Rifampicin is indicated in adults and children 12 years and older for the treatment of active pulmonary tuberculosis caused by $M$. tuberculosis. Rifampicin must always be used in combination with one or more antituberculosis drugs to which the isolate is susceptible $[7,8]$. In many countries, the wide use of the standard short-course regimen has led to an increasing incidence of multidrug-resistant (MDR) tuberculosis (TB), defined as resistance to at least isoniazid (INH) and Rifampicin. Mutations in rpoB, the gene encoding the $\beta$ subunit of DNA-dependent RNA polymerase, are associated with Rifampicin resistance in Mycobacterium tuberculosis [9]. Drug susceptibility of $M$. tuberculosis can be determined either by observation of growth or metabolic inhibition in a medium containing antituberculosis drug, or by detection, at the molecular level, of 
mutations in the genes related to drug action [10].

This Study aimed to screen the effect of Histidine as antimicrobial agent and interaction with antibiotics against pathogenic bacteria E.coli, Staph. aureus and TB isolates.

\section{Materials and Methods \\ Microorganisms:}

Two isolates of bacteria were used in this study including E. coli and Staph. aureus. These isolates were supplied by department of medical biotechnology/college of applied biotechnology. The isolates were re-purified and activated in enrichment and selected media (Eosin Methylene Blue, MacConky agar, Nutrient broth, Nutrient agar, Mannitol salt agar). These media were prepared according to the manufacturing company (Himedia).

\section{Histidine stock solution:}

It was prepared at a concentration of $100 \mathrm{mg} / \mathrm{ml}$ in deionized water and was sterilized using Millipore filter $(0.22 \mu \mathrm{m})$.

\section{Histidine medium:}

It was prepared by adding histidine at concentrations $0.1-10 \mathrm{mg} / \mathrm{ml}$ in Muellerhintone agar. Aliquot of $25 \mathrm{ml}$ of prepared medium with histidine was poured in petridishes for each concentration.

Antimicrobial susceptibility test was conducted using discs diffusion technique by distributionon the surface of the medium as shown in Table (1). These antibiotics were selected for each isolate according to the resistance and sensitive response of these isolates $[12,13]$.

Table (1)

Standards susceptibility tests of E. coli and Staph. aureus to the antimicrobial agents.

\begin{tabular}{|c||c||c||}
\hline \multirow{2}{*}{$\begin{array}{c}\text { Bactrial } \\
\text { isolate }\end{array}$} & \multicolumn{2}{|c|}{ Antimicrobial } \\
\cline { 2 - 3 } & Resistant to & Sensitive to \\
\hline \hline \multirow{4}{*}{ E. coli } & Vancomycine & \\
& Streptomycin & Tetracycline \\
& Metronidazole & Levofloxacin \\
& Cloxacilline & Ciprofloxacin \\
& Rifampicin & Nalidixic acid \\
& Penicillin & \\
\hline \hline \multirow{4}{*}{ Staph. } & Metronidazole & Vancomycine \\
aureus & Cloxacilline & Gentamycin \\
& Clarithromycin & Levofloxacin \\
& Rifampicin & Ciprofloxacin \\
& Tetracycline & Chloramphenicol \\
\hline
\end{tabular}

\section{M. tuberculosis (TB) response to histidine:}

The response of $\mathrm{TB}$ to the histidine was conducted in TB institute, Ministry of Iraqi health. The examination was done using the standard steps recommended by the World Health Organization and as follows [11]:

After characterization of the isolates as TB using ideal medium Lowenstein-Jensen medium (LJ medium ), two concentrations of Histidine 5 and $10 \mathrm{mg} / \mathrm{ml}$ were added to LJ-medium containing Rifampicin $40 \mu \mathrm{g} / \mathrm{ml}$. Previously identified TB isolates as Rifampicin -sensitive and resistance were used to inoculum these media. The inoculums of isolates were prepared by the staff of TB Institutes according to the standard procedure [11]. After inoculums, it was added to the media incubated at $37{ }^{\circ} \mathrm{C}$ for 30 - 40 days.

\section{Results and Discussion Effect of histidine:}

There was no effect of free Histidine at all concentrations used on the growth of Staph. aureus and E.coli and this result is not in agreement with Kacprzyka et al [3], who referred to the act of histidine as an antimicrobial agent.

\section{Susceptibility test:}

Table (2) showed the susceptibility test of E.coli against antibiotics in presence of serial concentrations of histidine ranged from 1 to $10 \mathrm{mg} / \mathrm{ml}$ in comparison with the control treatment without histidine and the presence of antibiotics. Control treatment illustrated the sensitivity of $E$. coli against Levofloxacin, Ciprofloxacin, Tetracycline, Vancomycine, Streptomycin and Nalidixic acid and resistant to Metronidazole, Cloxacilline and Penicillin according to [12]. There was no effect of His at different concentrations on the response of E. coli against (Vancomycine, Streptomycin, Metronidazole, Cloxacilline, Nalidixic acid and Penicillin). The sensitivity against Rifampicin and Tetracycline was increased and reduced against Levofloxacin and Ciprofloxacin starting from $1 \mathrm{mg} / \mathrm{ml}$ Histidine. For Staph. aureus (as shown in Table (3)), It was found the resistance of bacteria against Metronidazole, Clarithromycin, Rifampicin, Cloxacilline, Tetracycline and penicillin[12]. The sensitivity varied in presence of Histidine 
and increased for Rifampicin (> $3 \mathrm{mg} / \mathrm{ml}$ ), Tetracycline $(>1 \mathrm{mg} / \mathrm{ml})$ and reduced for Levofloxacin $(>1 \mathrm{mg} / \mathrm{ml})$ and Gentamycin $(>1 \mathrm{mg} / \mathrm{ml})$. No change in the sensitivity was found against Vancomycine, Chloramphenicol, Cloxacillin, Metronidazole and Clarithromycin. Interpretation change of the resistance and sensitivity to antibiotics may be due to influence of synergistic or

Table (2)

Effect of the serial concentration of histidine on susceptibility of E. coli.

\begin{tabular}{|c|c|c|c|c|c|c|c|c|c|c|c|}
\hline \multirow{3}{*}{ Type of Antibiotic } & \multicolumn{11}{|c|}{ Concentration of Histidine ( $\mathrm{mg} / \mathrm{ml})$} \\
\hline & \multicolumn{11}{|c|}{ Diameter of Inhibition zone ( $\mathrm{mm}$ ) } \\
\hline & $\overline{c \text { control }}$ & $\overline{11}$ & 2 & 3 & 4 & 5 & 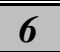 & 7 & 8 & $\overline{9}$ & 10 \\
\hline Streptomycin (S 10) & 14 & 22 & 20 & 20 & 19 & 20 & 20 & 18 & 17 & 14 & 12 \\
\hline Rifampicin (Rp 5) & 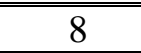 & 11 & 12 & 11 & 12 & 13 & 13 & 13 & 13 & $\overline{14}$ & 18 \\
\hline Metronidazole (Mz 5) & 0 & 0 & 0 & 0 & 0 & 0 & 0 & 0 & 0 & 0 & 0 \\
\hline Cloxacillin (Cx 5) & 0 & 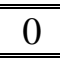 & 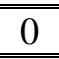 & 0 & 0 & 0 & 0 & 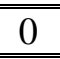 & 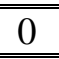 & 0 & 0 \\
\hline Levofloxacin (Lev 5) & 44 & 35 & 40 & 36 & 40 & 37 & 31 & 26 & 22 & 23 & 24 \\
\hline Ciprofloxacin (Cip 5) & 35 & 25 & 25 & 23 & 26 & 20 & 22 & 25 & 24 & 24 & 24 \\
\hline Tetracycline (T30) & 24 & 35 & 30 & 28 & 25 & 32 & 30 & 30 & 27 & 30 & 32 \\
\hline Naldixic acid (Na30) & 28 & 24 & 28 & 28 & 30 & 20 & 20 & 22 & 25 & 26 & 25 \\
\hline Pencillin (P 10) & 16 & 14 & 14 & 13 & 14 & 13 & 12 & 13 & 13 & 13 & 13 \\
\hline Vancomycin (Va30) & 14 & 14 & 14 & 13 & 14 & 12 & 13 & 14 & 12 & 13 & 14 \\
\hline
\end{tabular}

Table (3)

Effect of the serial concentrations of histidine on susceptibility of Staph. aureus.

\begin{tabular}{|c|c|c|c|c|c|c|c|c|c|c|c|}
\hline \multirow{3}{*}{ Type of Antibiotic } & \multicolumn{11}{|c|}{ Concentration of Histidine ( $\mathrm{mg} / \mathrm{ml})$} \\
\hline & \multicolumn{11}{|c|}{ Diameter of Inhibition zone ( $\mathrm{mm}$ ) } \\
\hline & control & 1 & 2 & 3 & 4 & 5 & 6 & 7 & 8 & 9 & 10 \\
\hline Metronidazole (Mz5) & 0 & $\overline{0}$ & $\overline{0}$ & 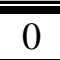 & $\overline{0}$ & 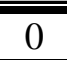 & 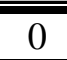 & 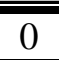 & $\overline{0}$ & 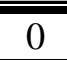 & $\overline{0}$ \\
\hline Vancomycin (Va30) & 10 & 10 & 10 & 10 & 12 & 10 & 10 & 10 & 10 & 10 & 10 \\
\hline Cloxacillin (Cx5) & 0 & 0 & 0 & 0 & 0 & 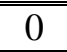 & 0 & 0 & 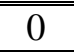 & 0 & 0 \\
\hline Clarithromycin (Cla15) & 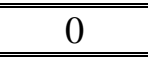 & 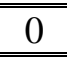 & 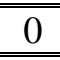 & 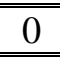 & 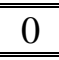 & 0 & 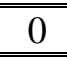 & 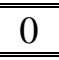 & 0 & 0 & 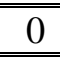 \\
\hline Rifampicin (Rp5) & 0 & 0 & 0 & 8 & 12 & 15 & 16 & 15 & 16 & 15 & 16 \\
\hline Gentamicin (Gm120) & 30 & 30 & 27 & 30 & 27 & 20 & 20 & 23 & 20 & 23 & 20 \\
\hline Levofloxacin (Lev5) & $\overline{40}$ & 35 & 40 & 35 & 30 & 25 & 25 & 27 & 30 & 25 & 30 \\
\hline Ciprofloxacin (Cip5) & 22 & 22 & 24 & 26 & 28 & 26 & 25 & 26 & 25 & 24 & 26 \\
\hline Tetracyclene (T 30) & 10 & 13 & 14 & 14 & 14 & 13 & 15 & 15 & 15 & 15 & 15 \\
\hline Cloramphinicol (C30) & 22 & 21 & 21 & 21 & 21 & 21 & 21 & 21 & 21 & 21 & 21 \\
\hline
\end{tabular}

\section{Effect of Histidine on response of TB}

Tables (2) and (3) exhibit clear that the response to the Rifampicin is increasing for E.coli and Staph. aureus at low concentrations of Histidine (>1 and $>3 \mathrm{mg} / \mathrm{ml}$ respectively). In cases of Multidruge resistant isolates (MDR), the common effective antibiotic for antagonistic of Histidine with antibiotics. In the case of Rifampicin and Tetracycline, there was an increase in the sensitivity for each isolates and the antagonistic interactions appeared in reducing the efficiency of antibiotic. 
with 5 and $10 \mathrm{mg} / \mathrm{ml}$ of histidine. The change in response of the resistant isolates may be due to the interaction of $\mathrm{Rp}$ with Histidine and invaded anthor targets in the $\beta$ subunit of DNA-dependent RNA polymerase responsible for most of the variation in $\mathrm{Rp}$ resistance appeared or may the Histidine played the defect complement in reverse the mutant isolate. These new hypothesis needs more investigation at the molecular level.

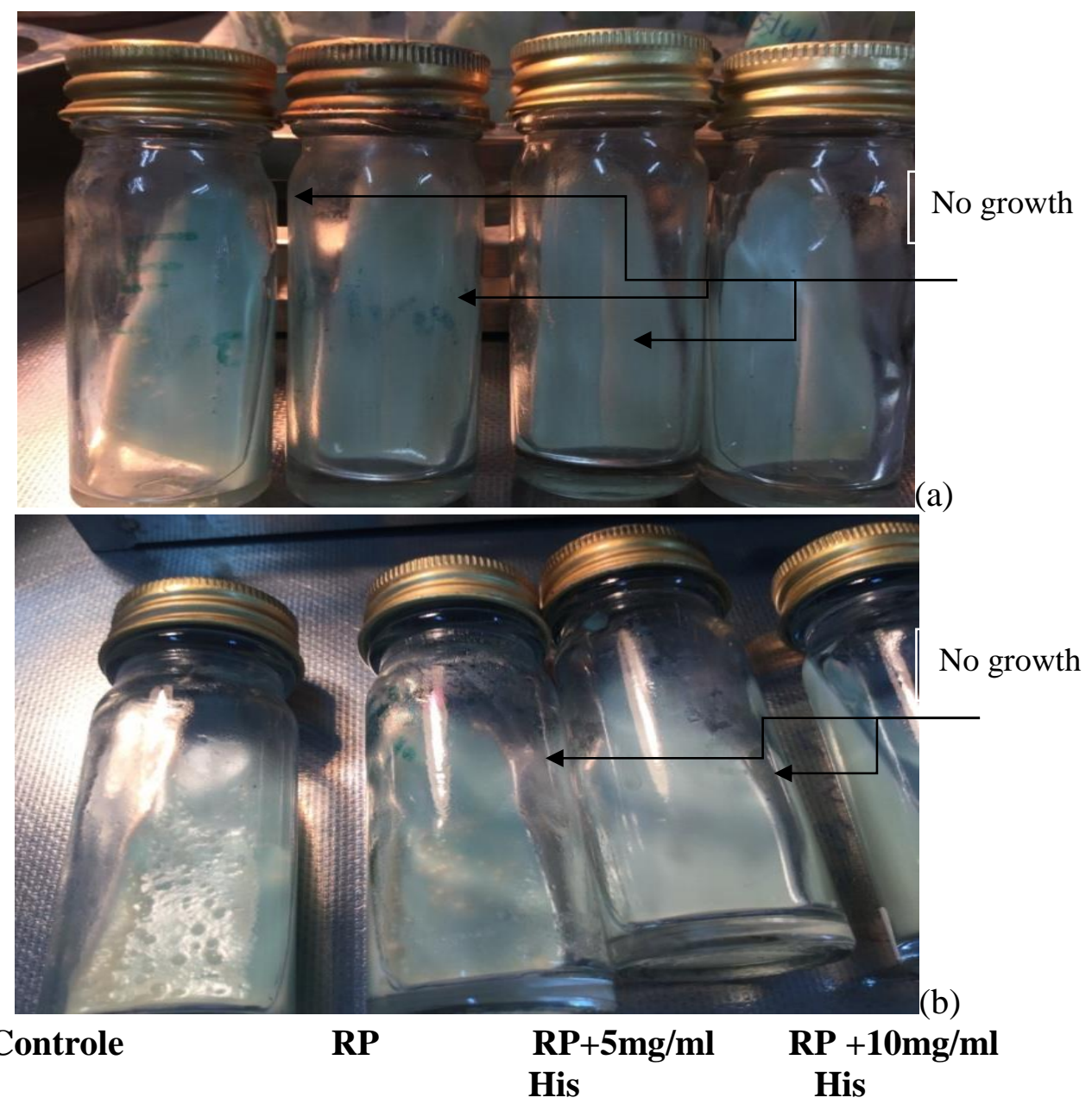

Fig.(1): Growth of Mycobacterium tuberculosis in LJ-medium in presence of Histidine. a, Rifampicin sensitive isolate; b, Rifampicin resistant isolate.

\section{References}

[1] Department of Biochemistry and Molecular Biophysics. University of Arizona August 25, 2003. http://www.biology.arizona.edu.

[2] Robert, A.I. "Histidine Biosynthesis". Arabidopsis Bookv. 9, PMC3266711, 2011.

[3] Lukasz, K.B.I., Victoria, R.B.I., Mathias, M., Mina, D., Mukesh, P., Martin, M. and Artur, S. "Antimicrobial activity of histidine-rich peptides is dependent on acidic condition. Biochem Biophys Acta". 2007, 1768(11): 2667-8.
[4] The American Society of Health-System Pharmacists. Retrieved Aug 1, 2015.

[5] Campbell, E.A., Korzheva, N., Mustaev, A., Murakami, K., Nair, S., Goldfarb, A. and Darst, S.A. "Structural mechanism for rifampicin inhibition of bacterial RNA polymerase". Cell, 104 (6): 901- 12, 2001.

[6] Feklistov, A., Mekler, V., Jiang, Q., Westblade, L.F., Irschik, H., Jansen, R., Mustaev, A., Darst, S.A. and Ebright, R.H. "Rifamycins do not function by allosteric modulation of binding of $\mathrm{Mg} 2+$ to the RNA polymerase active center". Proc Natl Acad Sci USA 105 (39): 14820-5, 2008. 
[7] Sterling, T. R., Villarino, M. E., Borisov,

and Chaisson, R.E. "Three months of rifampicin and isoniazid for latent tuberculosis infection". New England Journal of Medicine, 365(23), 2155-16, 2011.

[8] World Health Organization. Antituberculosis drug resistance in the world. Third global report. The WHO/IUATLD Global Project on Anti-Tuberculosis Drug Resistance Surveillance (WHO/CDC/TB/2004). Geneva, World Health Organization document, 2004 (In press) The NCCLS M7-A6

[9] Geneva, World Health Organization document. "Anti-tuberculosis drug resistance in the world". Report No. 2: prevalence and trends. The WHO/IUATLD Global Project on Anti-Tuberculosis Drug Resistance Surveillance, 2000.

[10] Michael, P.C. and Mark, R.S. "Few amino acid positions in rpo $\mathrm{B}$ are associated with most of the rifampin resistance in Mycobacterium tuberculosis" BMC, 5:173, 2004.

[11] Canetti, G., Fox, W. and Khomenko A. "Advances in techniques of testing mycobacterial drug sensitivity, and the use of sensitivity tests in tuberculosis control programmes". Bull World Health Org. 41:21-43, 1996.

[12] CLSI. Performance Standards for Antimicrobial Susceptibility Testing; Twenty-Fourth Informational Supplement. CLSI document M100-S24. Wayne, PA: Clinical and Laboratory Standards Institute; 2014.

[13] Harries, A., Maher, D. and Graham, S. “TB/HIV A Clinical Manual”. $2^{\text {nd }}$. Geneva: WHO/HTM/TB. p. 51-3, 2004.

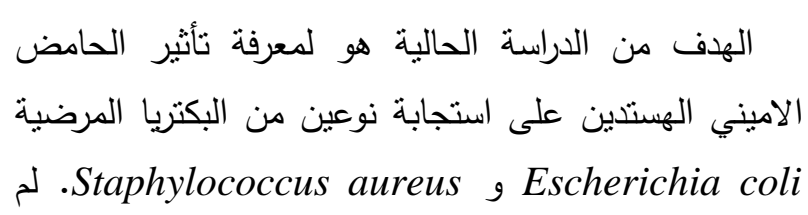
يلاحظ تأثثر مباشر لإضافة تراكيز مختلفة من الحامض الاميني الهستدين على كلا النوعين من البكتريا. تم اجراء

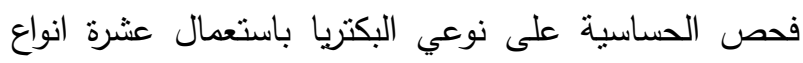

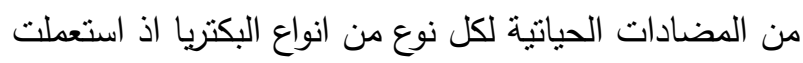

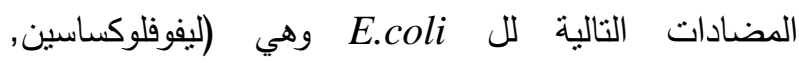
ستريبتومايسين, ريفامبسين, ميترانيدازول, كلوكساسلين, سبروفلوكساسين, تيتراسايكلين, نالديكسك اسيد, بنسلين,

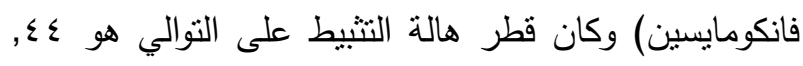
ع ا, ^, • , •, اضافة الحامض الاميني الهيتدين الى الوسط الزرعي مولر

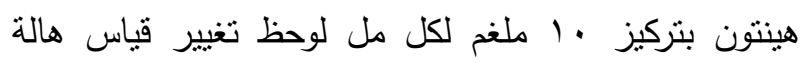
التثبيط ملم. اما بالنسبة لا Staph. aureus فقد تم استعمال المضادات التالية ليفوفلوكساسين, جينتامايسين, ريفامبسين, ميترانيدازول, كلوكساسلين, سيبروفلوكساسين, تيتراسايكلين, كلاريثرومايسين, فانكومايسين, كلورامفينيكول وكان قطر هالة

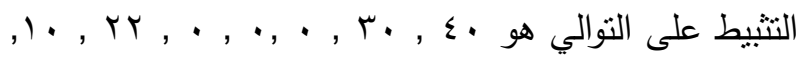

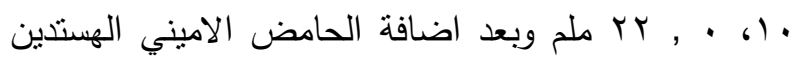
الى الوسط الزرعي مولر هينتون اكار بتركيز • •1 ملغم لكل

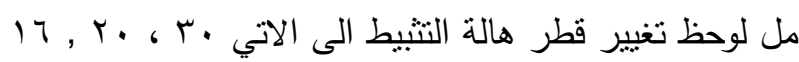

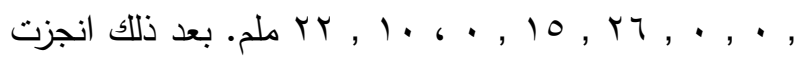
التجربة التطبيقية على عزلات حساسة ومقاومة للريفامبسين لبكتريا السل Mycobacterium tuberculosis في معرد التدرن الرئوي في بغداد. وجد ان خلط الهيتدين مع المضاد قد غير من استجابة العزلة المقاومة وتحولت الى حساسة. هذه النتائج قد تشجع على عدم استعمال مضادات حياتية اكثر فعالية وضارة ضد العزلات المقاومة. 